\title{
Pulmonary Extramedullary Hematopoiesis Mimicking Plasmacytoma in a Patient with Multiple Myeloma
}

\author{
SULEYMAN BALDANE ${ }^{1}$, SERDAR SIVGIN ${ }^{2}$, LEYLAGUL KAYNAR ${ }^{2}$, ERSIN OZASLAN ${ }^{3}$, AFRA YILDIRIM ${ }^{4}$, OZLEM \\ CANOZ $^{5}$, BULENT ESER ${ }^{2}$ \\ ${ }^{1}$ Department of Internal Medicine, Faculty of Medicine, Selcuk University, Konya, Turkey \\ ${ }^{2}$ Department of Hematology, Faculty of Medicine, Erciyes University, Kayseri, Turkey \\ ${ }^{3}$ Department of Oncology, Faculty of Medicine, Erciyes University, Kayseri, Turkey \\ ${ }^{4}$ Department of Radiology, Faculty of Medicine, Erciyes University, Kayseri, Turkey \\ ${ }^{5}$ Department of Pathology, Faculty of Medicine, Erciyes University, Kayseri, Turkey
}

A 42-year-old male patient was admitted to our hospital for planning autologous hematopoietic stem cell transplantation (auto-HSCT). He was diagnosed as multiple myeloma (IgG type Kappa) in 2003. His physical examination was normal with no important abnormality on laboratory evaluation. Chest radiography performed for routine evaluation prior to transplantation revealed a large, welldefined mass, that had obtuse angles with the chest wall consistent with extraparenchymal lesion superposed on second and third ribs. Also, there were multiple bony structures demonstrating changes of destructive effects of multiple myeloma. Computed tomography (CT)-guided biopsy was obtained from the mass by transthoracic fine-needle aspiration (FNAB) method. Biopsy was reported as extramedullary hematopoiesis (EMH) contrary to our expectation of multiple myeloma.

Key words: extramedullary hematopoiesis, multiple myeloma, thorax, auto-HSCT.

\section{INTRODUCTION}

Extramedullary haematopoiesis (EMH) is a compensatory phenomenon in hematological diseases with insufficient blood cell production, either due to a bone marrow replacement disease (e.g. myelofibrosis) or hemolytic anaemia with ineffective erythropoesis (e.g. beta thalassaemia, sickle cell anaemia, and hereditary spherocytosis) [1]. EMH usually affects the liver, spleen, and lymph nodes, while the intrathoracic cavity is less frequently involved $[2,3]$. Here, we describe a patient with multiple myeloma who was evaluated for autologous hematopoietic stem cell transplantation (autoHSCT), presenting with an incidental mass on the chest wall suggesting relapsed disease.

\section{CASE REPORT}

A 42-year-old male patient was admitted to Dedeman Stem Cell Transplantation Hospital, Erciyes University, Kayseri, Turkey for performing auto-HSCT. He was diagnosed with multiple myeloma (IgG type Kappa) in 2003, was treated with vincristine, doxorubicin plus high-dose dexamethasone protocol (VAD) and bortezomibe.
Peripheral blood stem cell mobilisation procedure was performed with Melphalan $200 \mathrm{mg}$ per body area $\left(\mathrm{m}^{2}\right)$. He was hospitalized for pre-transplant evaluation and preparation procedures. He had no history of alcohol consumption or smoking, but a history of bacterial meningitis at the time of chemotherapy administration. His vital signs were: arterial blood pressure $120 / 85 \mathrm{~mm} \mathrm{Hg}$, heart rate $84 / \mathrm{min}$, breath rate $20 / \mathrm{min}$ and body temperature $36.7^{\circ} \mathrm{C}$. His physical examination was normal with no important abnormality on laboratory evaluation. The laboratory analyses results were as follows: white blood cell $4.410^{9} / \mathrm{L}$ (normal range (NR): 4.810.8), haemoglobin $14.6 \mathrm{~g} / \mathrm{dL}$ (NR: 14-18), platelet count $25810^{9} / \mathrm{L}$ (NR:150-400), erythrocyte sedimentation rate $17 \mathrm{~mm} / \mathrm{h}$ (NR:0-20), alanine amino transferase $24 \mathrm{u} / \mathrm{L}$ (NR:10-49), creatinine $0.98 \mathrm{mg} / \mathrm{dL}$ (NR:0.7-1.3), albumin 5.1 g/dL (NR: 3.2-4.8), ferritin $103.3 \mathrm{ng} / \mathrm{mL}$ (NR: 28.5-306).

We performed bone marrow aspiration and found plasma cells with a rate of 3-4\% suggesting status of remission. In his frontal chest radiography performed for routine control prior to the transplantation, a large, well-defined mass, that had obtuse angles with the chest wall consistent with extraparenchymal lesion superposed on second and third ribs, was detected. In addition, there were 
multiple bony structures demonstrating changes of destructive effects of multiple myeloma (Figure 1).

The axial non-contrast thoracic computed tomography (CT) image showed the mass arising from third rib and that mass containing low density areas suggesting necrosis. Also destruction of the third rib was observed (Figure 2). A decision to perform CT-guided biopsy was taken. A specimen was obtained with CT-guided biopsy from the mass by transthoracic fine-needle aspiration (FNAB) method. No complication was observed due to operation procedure. The pathological evaluation of the sample obtained from the mass was reported as EMH unexpectedly different from multiple myeloma (Figure 3).

The patient underwent auto-HSCT in our hospital and he was discharged on good health after engraftment was achieved.

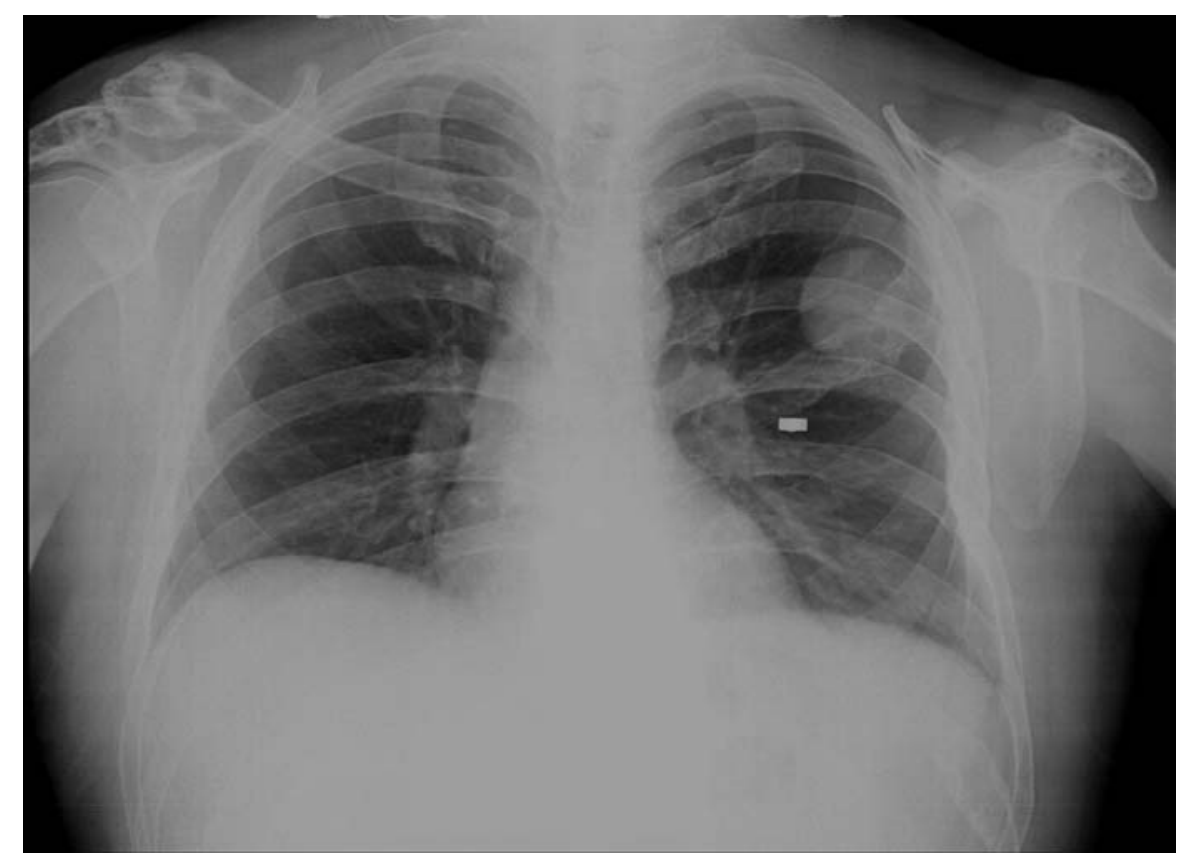

Figure 1. The frontal chest radiograph shows a large, well-defined mass on the left side of the thorax.

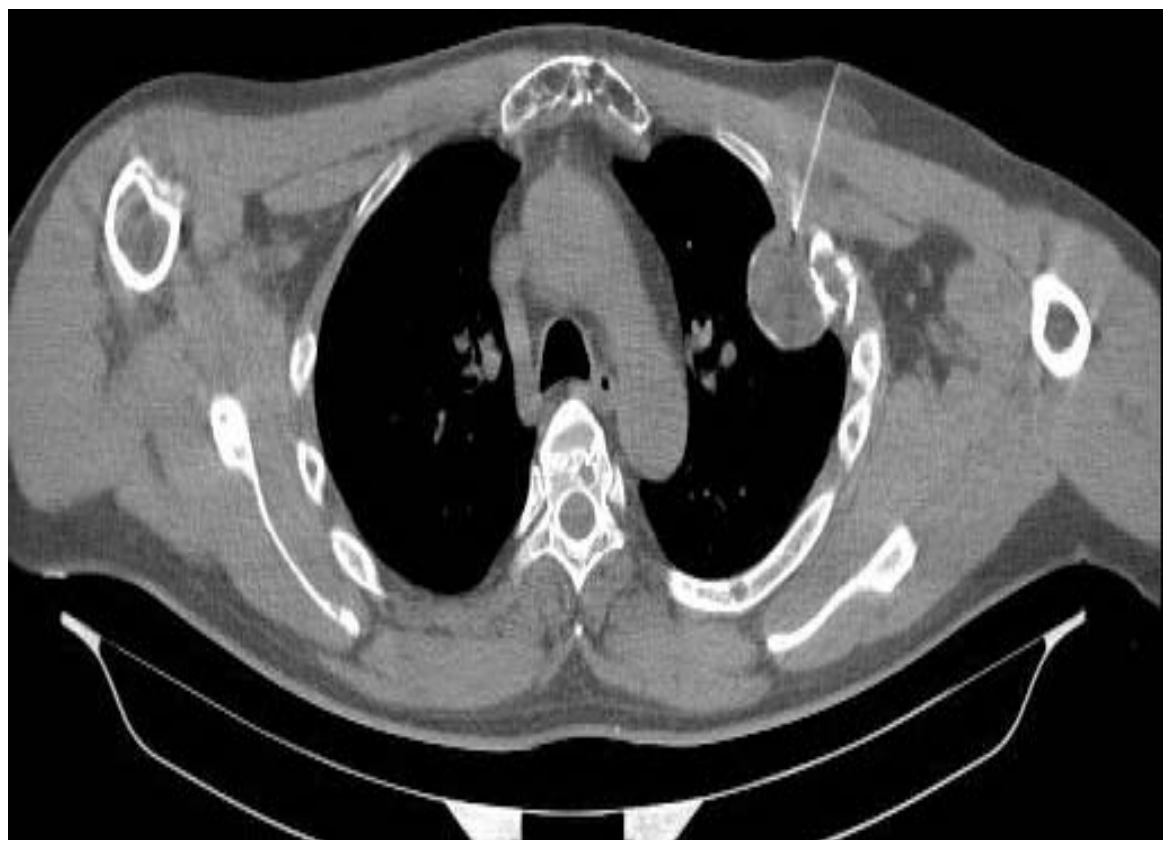

Figure 2. CT-guided biopsy, a specimen obtained from the mass arising from the third rib shown by an arrow. 


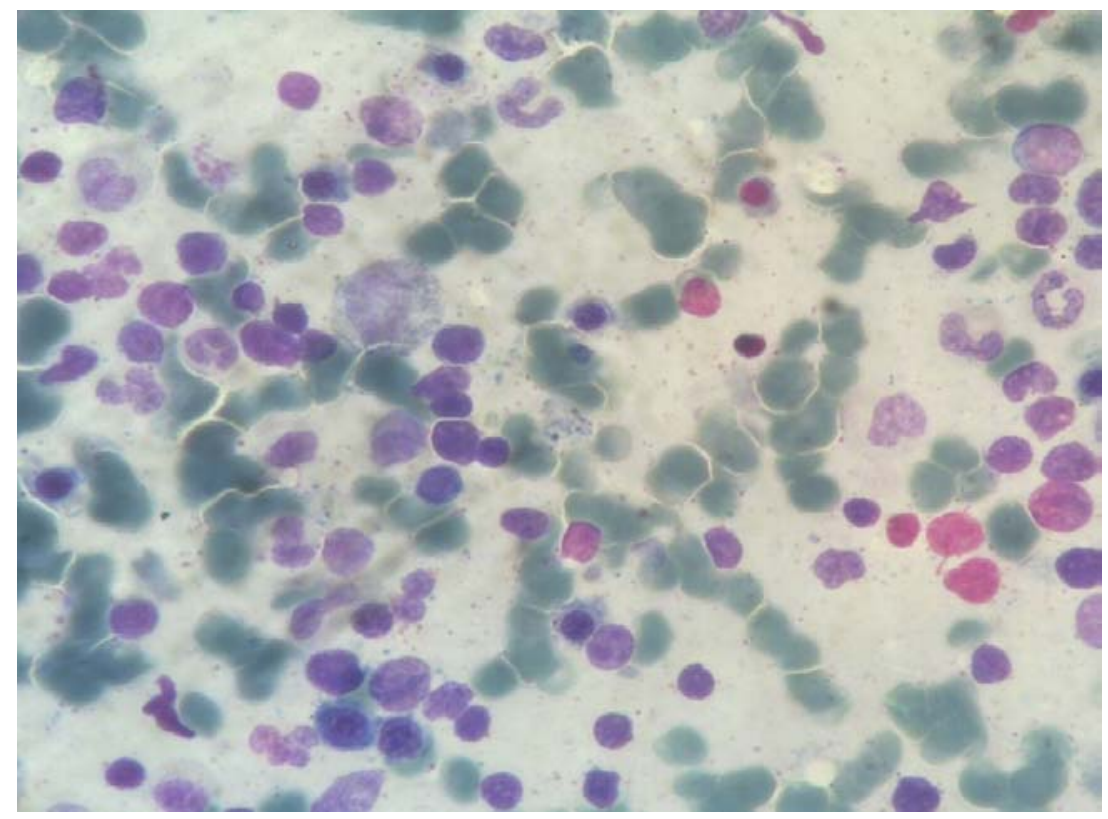

Figure 3. Erythroid precursors, myeloid precursors and megakaryocytes from aspiration material $(1000 \times$ magnification, Giemsa staining, aspiration cytology from the lesion).

\section{DISCUSSION}

Intrathoracic EMH is uncommon but well described. There are case reports and small series of EMH manifested as pleural based tumors and paraspinous masses [4]. Intrathoracic EMH may manifest as a paraosseous mass, interstitial pulmonary abnormality, pleural mass, or hemothorax, either alone or in combination. Paraosseous EMH is the most common manifestation of intrathoracic EMH. It appears as a small or large mass adjacent to the vertebrae mostly bilateral, ribs (commonly multiple), or both. These masses are usually asymptomatic and may be discovered incidentally $[5,6]$. When a patient with a previously diagnosed hematological disease presents the typical radiographic manifestations, the diagnosis of intrathoracic EMH can be safely established and there is no need of further invasive studies. Because of the highly vascular nature of the masses, biopsy and surgical resection should be avoided in order to prevent hemorrhage [7].

In our patient, the mass was located on third rib with destruction of the bone. The patient had no complaints related with the mass effect or secondary to the underlying disease. So, firstly the patient was thought to have relapsed disease presenting with the mass located on the chest wall. Nevertheless, the clinical and laboratory features of the patient suggested that the patient was in remission. Also, the location of the mass was not a typical site for patients with multiple myeloma whom had relapsed. This was a state to ensure that the mass was a plasmacytoma or not.

Treatment of intrathoracic EMH is usually not indicated except for the presence of some probable complications. The hematopoietic tissue is highly radiosensitive, so low-dose radiation has been offered as an effective method to control symptomatic spinal cord compression [8] and haemothorax [2, 3, 9].Surgical literature suggests that invasive measures be reserved for evacuation of clot, debulking of a mass causing compressive symptoms, or if a diagnosis cannot be made by other modalities [9]. The surgical literature also suggests that sclerotherapy should be contraindicated in these patients because the inflammation caused by the sclerosing agent may cause irritation of the EMH tissue leading to continuous bleeding [9].

Our patient had no complaints related with the mass so we did not need to decide about the treatment for EMH mass. His underlying disease required priority so we decided to perform autoHSCT first and then radiotherapy in the posttransplant period if needed.

Co-existence of multiple myeloma and EMH is very rare. Previously a few cases reported EMH with multiple myeloma [10, 11].

In conclusion, this case shows that EMH should be thought as a probable clinical entity in not only common disorders like chronic myeloproliferative disorders or congenital hemolytic anemia, but also rare disorders like multiple myeloma. 
Un pacient de sex masculin în vârstă de 42 de ani a fost internat în cadrul spitalului nostru în vederea realizării transplantului autolog de celulă stem hematopoietică (auto-HSCT). Acesta fusese diagnosticat în $2003 \mathrm{cu}$ mielom multiplu. La examenul clinic şi la analizele de laborator nu s-au observat modificări. Radiografia toracică de control a arătat o masă radioopacă, bine definită, cu unghiuri obtuze sugerând o leziune extraparenchimatoasă ce se suprapunea cu coastele II şi III. În plus existau modificări osoase caracteristice mielomului multiplu. Biopsia ghidată CT a permis obținerea materialului bioptic folosind aspirație transtoracică pe ac fin. Analiza materialului bioptic a arătat prezența țesutului hematopoietic extramedular contrar aşteptării de mielom multiplu.

Correspondence to: Suleyman Baldane, MD, Department of Internal Medicine,

Selcuk University, Konya, Turkey

Tel.: +903322244685, Fax: +903322412184

E-mail: baldane42@hotmail.com

\section{REFERENCES}

1. KOCH CA, LI CY, MESA RA, TEFFERI A. Nonhepatosplenic extramedullary hematopoiesis: associated diseases, pathology, clinical course, and treatment. Mayo Clin Proc 2003; 78:1223-1233.

2. BARTLETT RP, GREIPP PR, TEFFERI A, CUPPS RE, MULLAN BP, TRASTEK VF. Extramedullary haematopoiesis manifesting as a symptomatic pleural effusion. Mayo Clin Proc 1995; 70:1161-1164.

3. SMITH PR, MANJONEY DL, TEITCHER JB, CHOI KN, BRAVERMAN AS. Massive hemothorax due to intrathoracic extramedullary hematopoiesis in a patient with thalassemia intermedia. Chest 1988; 94:658-660.

4. VERANI R, OLSON J, MOAKE J. Intrathoracic Extramedullary hematopoiesis: report of a case in a patient with sickle-cell disease-beta-thalassemia. Am Clin Pathol 1980; 73:133-137.

5. AL-MARZOOQ YM, AL-BAHRANI AT, CHOPRA R, AL-MOMATTEN MI. Fine-needle aspiration biopsy diagnosis of intrathoracic extramedullary hematopoiesis presenting as a posterior mediastinal tumor in a patient with sickle cell disease: case report. Diagn Cytopathol 2004; 30:119-1921.

6. LALL C, PAYNE DK. A patient with anemia and a paraspinal chest mass. Chest 2003; 124:732-724.

7. MARCHIORI E, ESCUISSATO D L, IRION KL, et al. Extramedullary hematopoiesis: findings on computed tomography scans of the chest in 6 patients. J Bras Pneumol 2008; 34:812-816.

8. PAPAVASILIOU C, SANDILOS P. Effect of radiotherapy on symptoms due to heterotopic marrow in beta-thalassemia. Lancet 1987; 3:13-14.

9. KUPFERSCHMID JP, SHAHIAN DM, VILLANUEVA AG. Massive hemothorax associated with intrathoracic extramedullary hematopoiesis involving the pleura. Chest 1993; 103:974-975.

10. PALMA JA, DOMINGUEZ PD, RIVEROL M. Intracranial extramedullary hematopoiesis associated with multiple myeloma. Neurology 2013; 80:1620.

11. NASR SH, ALOBEID BB, OTRAKJI JA, MARKOWITZ GS. Myeloma cast nephropathy, direct renal infiltration by myeloma, and renal extramedullary hematopoiesis. Kidney Int 2008; 73:517-518.

Received May 13, 2015 